\title{
The obesity conundrum in sepsis
}

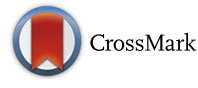

\author{
Pauline Yeung $\mathrm{Ng}^{1 *}$ and Matthias Eikermann²
}

\begin{abstract}
While the long-term negative effects of obesity on health is a well-studied phenomenon, its effects on acute illnesses seem to be the contrary. Several studies have indicated the possibility of an 'obesity paradox' in sepsis - where overweight and obese patients have better outcomes than normal weight patients. These meta-analyses including large numbers of patients across different countries raised an interesting but debatable topic. Results from metaanalyses of observational studies should be interpreted with caution, and a prove of association not be mistaken as prove of causality. Limitations common to such studies include inadequate adjustment for confounding and selection bias. More rigorous investigations to clarify any causal relationship between obesity and mortality in sepsis are needed.
\end{abstract}

Keywords: Obesity, Overweight, Sepsis, Septic shock, Obesity paradox, Mortality, ICU, Meta-analysis

\section{Background}

While the long-term negative effects of obesity on health is a well-studied phenomenon, its effects on acute illnesses seem to be the contrary. Many studies have indicated the possibility of an 'obesity paradox' - where overweight and obese patients have better outcomes than normal weight patients, in acute medical conditions such as acute coronary syndrome [1] and acute respiratory distress syndrome [2].

In a recently-published study in BMC Anesthesiology, Wang et al. analyzed the association between body weight and outcomes in septic patients in a metaanalysis of eight studies [3]. In their study, the authors concluded that overweight, but not obese or morbidly obese patients had lower adjusted mortality rates than normal weight patients. Although their work seems to be another obvious example of the obesity paradox and the benefits of having higher metabolic reserves in acute illnesses, the results must be interpreted with caution.

\section{Main text}

In 1997, the World Health Organization defined weight categories based on body mass index (BMI) cutoff values - underweight (BMI of <18.5), normal weight (BMI of 18.5 to $<25$ ), overweight (BMI of 25 to $<30$ ), and obesity (BMI of $\geq 30$ ) [4]. Recent studies have

* Correspondence: drpaulineyng@gmail.com

${ }^{1}$ Adult Intensive Care Unit, Queen Mary Hospital and The University of Hong Kong, Pok Fu Lam, Hong Kong

Full list of author information is available at the end of the article estimated that roughly $30 \%$ of the population in the United States are overweight, and another 30\% are obese [5]. Despite the widespread public health initiatives to reduce the prevalence of obesity and its related comorbidities, studies in the last decade have begun to show the possible protective effects of overweight in specific diseases - a phenomenon coined as the obesity paradox' [1, 2, 6, 7]. Our group also reported a similar observation: that in patients with obstructive sleep apnea - who are often obese - perioperative in-hospital mortality tends to be lower [8].

Two recent meta-analyses studied the obesity paradox in patients with sepsis. Pepper et al. included four retrospective and two prospective studies to show that overweight or obese BMIs reduced adjusted mortality in adults admitted to the intensive care unit with sepsis, severe sepsis, or septic shock [9]. In a more recent analysis, Wang and co-authors pooled data from three of the previously included studies with five additional studies, including 9696 patients, and concluded that overweight, but not obesity or morbid obesity, was associated with lower mortality in sepsis patients [3].

Several pathophysiological mechanisms have been postulated to explain the obesity paradox in critically ill patients with sepsis (Table 1). First, obesity may be associated with having higher metabolic reserves, which is beneficial in acute illnesses that are catabolic. Secondly, adipose tissues may modulate the inflammatory response by secreting anti-inflammatory mediators 
Table 1 Factors supporting and refuting the obesity paradox in sepsis

\begin{tabular}{ll}
\hline Possible pathophysiological mechanisms of the obesity paradox & Possible biases in studies examining the obesity paradox \\
\hline $\begin{array}{l}\text { Higher metabolic reserves in acute catabolic illnesses } \\
\text { Secretion of anti-inflammatory mediators by adipose tissue e.g. leptin, } \\
\text { soluble tumor necrosis factor-receptor-2 }\end{array}$ & $\begin{array}{l}\text { Inadequate adjustment for confounding factors e.g. smoking } \\
\text { Selection bias of patients with less severe sepsis in obese populations }\end{array}$ \\
$\begin{array}{ll}\text { Hemodynamic benefits of renin-angiotensin system activation } \\
\text { High-density lipoproteins bind bacterial lipopolysaccharide }\end{array}$ & $\begin{array}{l}\text { Protective effect limited to certain subpopulations e.g. older patients } \\
\text { with comorbidities }\end{array}$ \\
$\begin{array}{l}\text { Relatively restrictive administration of medications in obese patients } \\
\text { due to a non-weight based principle }\end{array}$ \\
ischemic preconditioning
\end{tabular}

such as leptin [10] and soluble tumor necrosis factorreceptor-2 [11]. Also, heightened renin-angiotensin system activation may confer hemodynamic advantages in sepsis [12].

However, meta-analyses of observational studies should be interpreted with caution, and a prove of association not be mistaken as prove of causality. The inclusion of retrospective studies poses the problem of inadequate adjustment for confounding. In particular, the underrepresentation of smokers in overweight and obese populations may bias lower mortality rates in these patient groups. Overweight and obesity may also have influenced the decision to admit otherwise less critically ill patients with sepsis, or patients with more easily-treatable infections, to intensive care, resulting in a selection bias [13]. Moreover, the protective effects of overweight may be limited to certain subpopulations, for example older and patients with existing comorbidities in fact, the mean age of one included study was more than 70 years [14]. The administration of intravenous fluids [13] by a non-weight based principle may be comparatively restrictive and benefit patients with higher BMIs [13]. Lastly, inaccuracies in measuring BMI during acute illness, for example the presence of tissue edema from fluid resuscitation, may have created misclassification of normal weight individuals into the overweight category.

\section{Conclusion}

Globally, the incidence of sepsis and the number of deaths related to sepsis are increasing. There is a pressing need to identify factors associated with increased sepsis-related mortality to better prognosticate patient outcomes and allocate intensive care resources. These meta-analyses including large numbers of patients across different countries raised an interesting but debatable example of the obesity paradox in sepsis. More rigorous investigations to clarify any causal relationship between obesity and mortality in sepsis are needed.

\section{Abbreviation}

BMI: Body mass index

\section{Acknowledgements}

None.

\section{Funding \\ Matthias Eikermann received funding from Jeffrey and Judith Buzen, and Merck Inc.}

\section{Availability of data and materials}

Not applicable.

\section{Authors' contributions}

Both authors read and approved the final manuscript.

Ethics approval and consent to participate

Not applicable.

\section{Consent for publication}

Not applicable.

\section{Competing interests}

Matthias Eikermann is a Section Editor of BMC Anesthesiology. The authors declare that they have no competing interests.

\section{Publisher's Note}

Springer Nature remains neutral with regard to jurisdictional claims in published maps and institutional affiliations.

\section{Author details}

${ }^{1}$ Adult Intensive Care Unit, Queen Mary Hospital and The University of Hong Kong, Pok Fu Lam, Hong Kong. ${ }^{2}$ Department of Anesthesia, Critical Care and Pain Medicine, Beth Israel Deaconess Medical Center and Harvard Medical School, 330 Brookline Avenue, Boston, MA, USA.

Received: 12 September 2017 Accepted: 9 October 2017

Published online: 25 October 2017

References

1. Niedziela J, Hudzik B, Niedziela N, Gasior M, Gierlotka M, Wasilewski J, Myrda K, Lekston A, Polonski L, Rozentryt P. The obesity paradox in acute coronary syndrome: a meta-analysis. Eur J Epidemiol. 2014;29(11):801-12.

2. Ni YN, Luo J, Yu H, Wang YW, YH H, Liu D, Liang BM, Liang ZA. Can body mass index predict clinical outcomes for patients with acute lung injury/ acute respiratory distress syndrome? A meta-analysis. Crit Care. 2017;21(1):36.

3. Wang S, Liu X, Chen Q, Liu C, Huang C, Fang X. The role of increased body mass index in outcomes of sepsis: a systematic review and meta-analysis. BMC Anesthesiol. 2017;17(1):118.

4. Obesity: preventing and managing the global epidemic. Report of a WHO consultation. World Health Organ Tech Rep Ser 2000, 894:i-xii, 1-253. 
5. Yang L, Colditz GA. Prevalence of overweight and obesity in the United States, 2007-2012. JAMA Intern Med. 2015;175(8):1412-3.

6. Fleischmann E, Teal N, Dudley J, May W, Bower JD, Salahudeen AK. Influence of excess weight on mortality and hospital stay in 1346 hemodialysis patients. Kidney Int. 1999:55(4):1560-7.

7. Gruberg L, Weissman NJ, Waksman R, Fuchs S, Deible R, Pinnow EE, Ahmed LM, Kent KM, Pichard AD, Suddath WO, et al. The impact of obesity on the short-term and long-term outcomes after percutaneous coronary intervention: the obesity paradox? J Am Coll Cardiol. 2002;39(4):578-84.

8. Shin CH, Grabitz SD, Timm FP, Mueller N, Chhangani K, Ladha K, Devine S, Kurth T, Eikermann M. Development and validation of a score for preoperative prediction of obstructive sleep apnea (SPOSA) and its perioperative outcomes. BMC Anesthesiol. 2017;17(1):71.

9. Pepper DJ, Sun J, Welsh J, Cui X, Suffredini AF, Eichacker PQ. Increased body mass index and adjusted mortality in ICU patients with sepsis or septic shock: a systematic review and meta-analysis. Crit Care. 2016;20(1):181.

10. Ahima RS. Adipose tissue as an endocrine organ. Obesity (Silver Spring). 2006;14(Suppl 5):242S-9S.

11. Winkler G, Kiss S, Keszthelyi L, Sapi Z, Ory I, Salamon F, Kovacs M, Vargha P, Szekeres O, Speer G, et al. Expression of tumor necrosis factor (TNF)-alpha protein in the subcutaneous and visceral adipose tissue in correlation with adipocyte cell volume, serum TNF-alpha, soluble serum TNF-receptor-2 concentrations and C-peptide level. Eur J Endocrinol. 2003;149(2):129-35.

12. Kershaw EE, Flier JS. Adipose tissue as an endocrine organ. J Clin Endocrinol Metab. 2004;89(6):2548-56.

13. Arabi YM, Dara SI, Tamim HM, Rishu AH, Bouchama A, Khedr MK, Feinstein D, Parrillo JE, Wood KE, Keenan SP, et al. Clinical characteristics, sepsis interventions and outcomes in the obese patients with septic shock: an international multicenter cohort study. Crit Care. 2013;17(2):R72.

14. Prescott HC, Chang WW, O'Brien JM, Jr., Langa KM, Iwashyna TJ: Obesity and 1-year outcomes in older Americans with severe sepsis. Crit Care Med 2014, 42(8):1766-1774.

\section{Submit your next manuscript to BioMed Central and we will help you at every step:}

- We accept pre-submission inquiries

- Our selector tool helps you to find the most relevant journal

- We provide round the clock customer support

- Convenient online submission

- Thorough peer review

- Inclusion in PubMed and all major indexing services

- Maximum visibility for your research

Submit your manuscript at www.biomedcentral.com/submit

) Biomed Central 